\title{
BEBERAPA PENDEKATAN SOSIOLOGIS \\ DALAM PENELITIAN KARAWITAN
}

\section{T. Slamet Suparn}

Sekolah Tinggi Seni Indonesia Surakarta

\section{Abstract}

Basically, several approaches from many different fields of study, such as history, philosophy, anthropology, psychology, economy and sociology, can be applied in any researches, including a research on karawitan. This writing explains how sociological approach is applied to study karawitan. Principally, this approach analyze the relationship between society and karawitan art, its literary values and the social values, the artists' background and the problems of art life in society. Several concepts and theories in sociology can be used to analyze karawitan as the object.

Key words: karawitan (a Javanese music), art and sociological approach

\section{A. Pendahuluan}

Kerangka konseptual dalam suatu penelitian digunakan dalam rangka untuk memperluas wawasan dan mempertajam sensitivitas teoritis peneliti dalam memahami fenomena-fenomena sosial yang ada di lapangan. Kerangka konseptual dalam suatu penelitian tidak digunakan oleh peneliti pada saat pengumpulan data, tetapi sebagai alat analisis data yang telah diperoleh dari lapangan. Kerangka konseptual juga tidak untuk menguji atau membuktikan suatu teori ataupun hipotesis. Oleh karena karawitan hidup di lingkungan masyarakat Jawa, untuk itu perlu dikemukakan mengenai konsep masyarakat Jawa. Di samping itu juga akan dikemukakan konsep karawitan sebagai seni, karawitan sebagai institusi, dan landasan teori yang dapat dimanfaatkan.

Dalam pembicaraan mengenai konsep masyarakat Jawa, dapat mengacu pada pemikiran Magnis Suseno, bahwa masyarakat Jawa adalah mereka yang bahasa ibunya bahasa Jawa (Suseno, 1988: 3). Di antara pemakai bahasa jawa, dapat dibedakan antara mereka yang secara sadar hidup sebagai orang Islam (Jawa Santri), dan mereka yang meskipun menamakan diri sebagai orang Islam, namun secara kultural lebih ditentukan oleh budaya pra-Islam (Jawa Abangan). Kategori kedua itulah yang digunakan dalam paper ini. Namun demikian, secara metodologis terdapat kesulitan, karena yang disebut "orang Jawa", sebetulnya memiliki individualitas yang kuat dan tidak ada yang khas tipe Jawa (ada yang perilakunya halus ada yang kasar, ada yang terbuka ada yang tertutup, ada yang bekerja keras ada yang malas, dan sejenisnya). Konsep ini menurut Magnis Suseno disebut sebagai metode konstruksi teoritis (Suseno, 1988: 4). 
Pulau Jawa semula terdapat empat jenis bahasa yang berbeda. Penduduk asli Jakarta berbicara dalam suatu dialek bahasa Melayu yang biasa disebut Melayu-Betawi. Jawa Barat bagian tengah dan selatan digunakan bahasa Sunda, sedangkan Jawa Timur bagian utara dan timur digunakan oleh imigran dari Madura yang tetap menggunakan bahasa Madura. Adapun di bagian Jawa lainnya orang berbicara bahasa Jawa. Namun demikian, bahasa Jawa yang digunakan di daerah dataran rendah pesisir utara Jawa Barat dari Banten sampai Cirebon, bukanlah bahasa Jawa yang sebenarnya. Bahasa Jawa yang sebenarnya digunakan di Jawa Tengah dan Jawa Timur, dan orang Jawa adalah orang yang bahasa ibunya yakni bahasa Jawa dalam arti yang sebenarnya. Jadi orang Jawa adalah penduduk asli bagian tengah dan timur pulau Jawa yang berbahasa Jawa, walaupun di wilayah-wilayah itu juga hidup bukan masyarakat Jawa (Suseno, 1988: 11, Koentjaraningrat, 1984: 4). Pada saat ini, banyak orang Jawa yang hidup sebagai transmigran di pulau-pulau luar Jawa, seperti di Sumatra (Lampung, Bengkulu), Sulawesi (Menado), dan sebagainya. Dari aspek kebudayaan Jawa, masih dibedakan antara penduduk pesisir utara yang banyak dipengaruhi kebudayaan Islam, sehingga menghasilkan kebudayaan Jawa yang khas, yakni kebudayaan pesisir, dan daerah-daerah pedalaman, yang sering disebut "kejawen", dengan pusat budaya dari kota kerajaan yakni Surakarta dan Yogyakarta, di samping karesidenan Banyumas, Kedu, Madiun, Kediri, dan Malang. Sebagian besar pulau Jawa bersifat agraris.

\section{B. Hakikat dan Konsep Karawitan}

\section{Karawitan Sebagai Seni.}

Karawitan merupakan salah satu jenis (genre) seni pertunjukan Jawa tradisional, memiliki beberapa elemen meliputi rombongan/group (pengrawit, pesindhen/suarawati), peralatan (gamelan), penanggap dan/atau penonton.

Karawitan secara tradisi menggunakan seperangkat gamelan laras slendro dan pelog yang sebagian besar terdiri atas instrumen pukul (perkusi) dari perunggu dan sebagian kecil instrumen gesek, tiup, dan petik. Instrumen-instrumen pukul yang terbuat dari bahan perunggu terdiri atas kemanak, gender, slentem, saron, bonang, ketuk, kenong, kempul, dan gong. Instrumen pukul yang terbuat dari bahan kayu yakni gambang, sedangkan instrumen pukul yang terbuat dari bahan kayu dan kulit adalah kendang. Instrumen tiup yang terbuat dari bahan bambu yakni suling, dan instrumen petik yang terbuat dari dua dawai yakni rebab, serta instrumen petik terdiri atas 13 dawai kembar (double) adalah siter dan celempung.

Instrumen-instrumen itu dimainkan oleh penabuh yang biasa disebut pengrawit. Kecuali pengrawit, dalam rombongan karawitan terdapat pula sejumlah wirasuara (vokalis laki-laki) dan suarawati atau pesindhen (vokalis perempuan). Instrumen gamelan yang berjumlah tidak kurang dari 20 jenis, dewasa ini dalam keperluan karawitan pakeliran, kadang oleh dalang masih ditambah beberapa instrumen perangkat musik Barat seperti cymbal, drum, keyboard, terompet, dan biola. Hal itu digunakan manakala membunyikan lagulagu Campursari dan lagu-lagu lain di luar tradisi karawitan.

Karawitan klenengan biasanya dimainkan pada malam hari dimulai jam 19.00 sampai dengan jam 00.00 atau pagi hari mulai pukul 09.00-14.00. Karawitan klenengan malam hari biasanya dibagi menjadi tiga bagian laras slendro, yakni bagian patet nem, patet sanga, dan patet manyura. Setiap bagian, secara tradisional memilki repertoar gending masing-masing. Pada klenengan pagi hari juga dibagi menjadi tiga bagian laras pelog, yakni bagian patet lima, patet nem, dan patet barang. Seperti dalam laras slesndro, setiap bagian secara tradisional memilki repertoar gending masing-masing. Namun demikian dalam kenyataannya tidak jarang klenengan pada malam dan/atau siang hari kedua laras itu disandingkan. Dengan demikian patet nem laras slendro disandingkan dengan patet lima laras pelog, patet sanga dengan patet nem laras pelog, dan patet manyura laras slendro dengan patet barang laras pelog.

Pengrawit merupakan figur sentral dalam dunia karawitan, karena dia berfungsi sebagai penggerak utama dari bunyi gamelan. Dia menafsirkan balungan gending melalui instrumen yang dimainkan sesuai karakter instrumeninstrumen itu. Dia menghantarkan penontonnya ke alam imajiner, dan membawanya ke suasana sedih, gembira, marah, manis, melengking keras, lirih, dan lain sebagainya. Dalam tradisi karawitan, pengrawit wajib memiliki kemampuan dasar sebagai persyaratan sebagai seorang pengrawit, yakni gendhingi. Gendhingi, berarti pengrawit dapat menguasai banyak repertoar gending, baik untuk keperluan konser maupun untuk pertunjukan lain. Pengrawit lewat teks/cakepan yang disajikan, juga dapat memberikan pesan kepada penonton mengenai ajaran spiritual yang biasa dilakukan oleh guru agama, nilainilai kemanusiaan, dll.

Elemen balungan gending juga cukup penting dalam karawitan. Dalam kosakata bahasa Jawa, balungan berarti suatu kerangka dasar yang digunakan sebagai acuan untuk membangun sesuatu. Balungan rumah merupakan kerangka dasar sebelum wujud rumah sepenuhnya terwujud. Jadi balungan gending dalam karawitan berarti kerangka dasar yang masih perlu diinterpretasikan oleh pengrawit agar menjadi sajian gending utuh. Elemen penting lain dalam karawitan yakni cakepan, suatu teks yang digunakan oleh suarawati dan/atu penggerong dalam gending tertentu. Cakepan dapat berisi suatu pengetahuan tertentu, atau peristiwa tertentu, yang mempunyai makna tertentu bagi masyarakat pada masa tertentu.

Karawitan secara tradisional berfungsi sebagai sarana ritual, hiburan, hayatan, dan komunikasi. Sebagai sarana ritual, ruwatan merupakan salah satu

Beberapa Pendekatan Sosiologis Dalam Penelitian Karawitan (T. Slamet Suparno) 
bentuk upacara untuk penyucian ritual guna mencegah kejahatan atau penyakit. Kecuali ruwatan, sebagai sarana ritual karawitan juga dapat digunakan untuk menyambut kelahiran putra raja, untuk penobatan raja, dan segala bentuk upacara. Fungsi kedua dari karawitan yakni sebagai hiburan. Karawitan sebagai hiburan biasanya dikaitkan dengan berbagai keperluan seperti hari jadi kota tertentu atau lembaga tertentu, khitan, mantu, seribu hari orang meninggal, dan hari kelahiran seseorang. Fungsi hiburan ini diperuntukkan bagi para penonton yang diundang oleh si empunya kerja, dan kadang ada banyak penonton yang berdatangan tanpa diundang oleh si empunya kerja.

Fungsi ketiga dari karawitan yakni fungsi hayatan. Pertunjukan ini biasanya memerlukan garapan serius, karena penonton yang pada umumnya membeli tiket menuntut adanya sajian yang bermutu. Biasanya penonton pertunjukan ini dari kalangan menengah ke atas, seperti para elit nasional, para bangsawan (dahulu), para pengusaha, para karyawan perusahaan, dan para pedagang. Secara naluriah, mereka memiliki perilaku estetik, oleh karenanya mereka ingin menikmati tontonan yang berkualitas yang dapat dinikmati kapan saja dan di mana saja.

Fungsi keempat dari karawitan yakni sebagai sarana komunikasi. Lewa sarana komunikasi ini, kaum elit yang berkuasa dapat menyebarkan ide-ide, kepercayaan, dan sistem nilai. Sebagai sarana komunikasi, karawitan merupakan suatu alat yang paling penting untuk mencapai penduduk yang masih buta aksara, baik yang ada di pedesaan maupun yang ada di kota-kota. Para ulama, pendeta, dan guru-guru agama telah memainkan peran penting dalam mempropagandakan ide-ide keagamaan mereka. Walaupun demikian, manfaat karawitan untuk mendidik penonton tidaklah unik di daerah budaya Jawa.

Elemen penting lainnya yakni pakem. Dalam konteks paper ini cenderung mengikuti pendapat Umar Kayam bahwa pakem merupakan seperangkat aturan tersurat maupun tersirat, lisan maupun tertulis, mengenai satu atau beberapa elemen karawitan dari wilayah gaya tertentu yang membuatnya berbeda dengan karawitan dari wilayah gaya lain (Kayam, 2001: 65). Perangkat aturan itu selalu ada di sepanjang sejarah karawitan Jawa, walaupun dia selalu tidak abadi, karena dapat berubah sesuai dengan situasi dan kondisi historis dari suatu masa tertentu.

Namun demikian pakem itu pun tidak serta merta diterima secara homogen oleh setiap pengrawit atau komunitas karawitan, karena masih kuatnya budaya lisan yang membingkai lingkungan sosio-kultural seni karawitan yang bersangkutan, bahkan lingkungan sosio-kultural Jawa pada umumnya. Oleh karena itu, dalam kasus karawitan, kemungkinan elemen pembeda gaya Surakarta dengan gaya yang lain menunjuk misalnya pada pola tabuhan gending, dan repertoar gending. Jadi walaupun karawitan terdapat beberapa macam gaya, selalu

Imaji, Vol.4, No.2, Agustus 2006 : 154 - 176 dapat ditangkap satu ciri umum yang dapat membedakan dengan wilayah gaya yang lain.

2. Karawitan sebagai Institusi.

Salah satu elemen penting dalam pertunjukan adalah konsep grup/ rombongan (Brandon, 1967: 171). Bila genre membatasi dimensi-dimensi artistik, rombongan membatasi dimensi sosialnya. Genre ada apabila ada pemain yang mengadakan pertunjukan, dan dia mati jika para pemainnya berhenti mengadakan pertunjukan. Seakan-akan genre merupakan jiwa dari pertunjukan, sedangkan rombongan merupakan badan wadag-nya. Seni pertunjukan yang paling indah memerlukan badan wadag dari rombongan atau organisasi sosial untuk dapat meragakan dan melestarikan dirinya.

Rombongan pertunjukan merupakan sebuah organisasi sosial, yang selalu beradaptasi dengan lingkungan sosio-politik, sosio-ekonomi, dan berelasi dengan organisasi-organisasi sosial lainnya. Demikian pula karawitan merupakan suatu organisasi sosial. Berapa banyak rombongan karawitan gaya Surakarta yang berdomisili di wilayah kebudayaan Surakarta terlalu sulit untuk dipastikan. Hal ini mengingat bahwa dari sejumlah rombongan karawitan yang ada, tidak semua rombongan selalu mengadakan pertunjukan setiap bulan. Dari hasil penelitian yang dilakukan Umar Kayam pada tahun 1993-1995, jumlah rombongan pakeliran (berarti juga grup karawitan pakelirannya) di wilayah kebudayaan Surakarta 462 buah (Kayam, 2001: 36). Dari sejumlah itu di kota Surakarta 6 buah, kabupatenkabupaten Wonogiri sejumlah 397 buah, Sukoharjo 7 buah, Klaten 10 buah, Boyolali 7 buah, Sragen 17 buah, dan Karanganyar 18 buah.

Beberapa faktor penting yang mempengaruhi lokasi rombongan karawitan yakni bahasa, penduduk, kondisi ekonomi, agama, dan tradisi-tradisi budaya (Brandon, 1967: 174). Sebagian besar rombongan karawitan mengadakan pertunjukan di wilayah di mana bahasa yang digunakan penonton sama dengan bahasa yang digunakan dalam pertunjukan. Rupanya penduduk merupakan faktor kedua yang mempengaruhi penyebaran rombongan karawitan. Secara jelas tidak ada rombongan di wilayah yang tidak ada orang yang berperan sebagai penonton, misalnya di tengah hutan. Namun demikian juga tidak berarti bahwa suatu wilayah yang besar penduduknya berarti besar pula jumlah rombongan di wilayah itu. Kota-kota besar belum tentu memiliki rombongan karawitan lebih secara proporsional dari pada kota-kota kecil.

Kondisi ekonomi lokal tampaknya merupakan faktor ketiga yang mempengaruhi persebaran rombongan karawitan. Biasanya karawitan dilakukan di tempat penanggap yang berkecukupan secara finansial, baik penanggap secara perorangan ataupun penanggap secara institusi sosial. Namun demikian, kadang ada penanggap yang sebetulnya kurang mampu dalam segi finansial, namun juga

Beberapa Pendekatan Sosiologis Dalam Penelitian Karawitan (T. Slamet Suparno) 
mengadakan klenengan, bahkan oleh rombongan karawitan terkenal. Hal ini kemungkinan dilatarbelakangi oleh pemahaman mengenai status sosial, agar dia tetap dapat dihargai oleh masyarakat sekitarnya.

Agama rupanya juga dapat mempengaruhi persebaran rombongan karawitan di suatu wilayah. Sebagai contoh di wilayah kebudayaan pesisir utara Jawa di mana masyarakat sebagian besar beragama Islam, jumlah rombongan karawitan tidak sebanyak di wilayah kebudayaan Surakarta. Hal itu mengingat bahwa karawitan yang bermotivasi agama Islam tidaklah umum, walaupun kadang karawitan berkaitan dengan peristiwa agama.

Tradisi-tradisi budaya masa lampau rupanya memainkan peran yang paling penting di mana rombongan karawitan berada. Sebagai contoh di wilayah kebudayaan Surakarta, terdapat paling banyak rombongan karawitan di banding dengan wilayah kebudayaan lain seperti Banyumas, Bagelen, dan pesisir. Hal itu bukan karena kondisi ekonomi wilayah kebudayaan Surakarta paling kaya, dan juga bukan karena bahasa Jawa hidup subur di wilayah kebudayaan Surakarta, tetapi karena peristiwa-peristiwa sejarah. Surakarta merupakan salah satu ibu kota terkuat di pulau Jawa beberapa abad yang lalu. Karawitan dibina dengan penuh perhatian oleh istana Surakarta, dan tentu saja tradisi ini menyebar di wilayah sekitar istana. Walaupun saat ini istana Surakarta sudah sangat jarang mengadakan klenengan, namun pengaruh tradisi istana ini dapat dirasakan di mana-mana. Pengrawit hidup di wilayah ini, karena penonton sudah terbiasa dengan karawitan dan ingin menyaksikannya. Kecuali itu, karena penonton menghendaki klenengan maka pengrawit terus mengadakan pertunjukan dan hidup dalam jumlah yang cukup di wilayah kebudayaan Surakarta.

Kembali kepada konsep rombongan, bahwa rombongan adalah unit semi-permanen yang di seputarnya pertunjukan mengorganisasi diri. Tentu saja rombongan dapat dipandang sebagai grup yang berproduksi dan yang berfungsi secara artistik, namun juga dapat dipandang sebagai sebuah institusi sosial. Sebagai institusi sosial, dia mempunyai suatu identitas di dalam masyarakat dan memiliki struktur internal serta memiliki hubungan dengan organisasi sosial lainnya. Demikian pula dengan rombongan karawitan yang ada di wilayah kebudayaan Surakarta.

Rombongan karawitan terdiri atas pengrawit, pesindhen, penggerong, dan pekerja di belakang panggung. Dalam melaksanakan pergelaran, didukung lebih kurang 25 orang pengrawit, empat orang vokalis laki-laki (wirasuara/ penggerong), dan tiga sampai lima orang vokalis perempuan (pesindhen/ suarawati). Rata-rata dalam mengadakan pertunjukan tidak menggunakan perangkat gamelan pengrawitnya sendiri, namun biasanya disewakan oleh yang empunya hajat. Kecuali itu, ada pembantu di belakang layar yakni seorang penata

Imaji, Vol.4, No.2, Agustus 2006 : 154 - 176 gamelan yang disebut peniti, dan saat ini dibantu oleh teknisi sound-system. Beberapa tahun lalu, banyak grup karawitan yang memiliki anggota grup merupakan keluarga dan tetangga, bahkan ada beberapa pengrawit yang isterinya adalah pesindhen.

Keberadaan rombongan karawitan juga dipengaruhi oleh lingkungan sosial di luar yang dengannya rombongan itu mempunyai hubungan. Hubungan eksternal yang penting adalah rombongan karawitan lain dan perwakilan pemerintah. Sebagian besar rombongan karawitan di wilayah kebudayaan Surakarta memiliki anggota tetap, namun demikian rombongan lokal banyak yang tidak memiliki anggota tetap. Oleh karena itu bagi rombongan karawitan lokal sering terjadi pinjam meminjam pengrawit dan pesindhen manakala tidak bersamaan waktu petunjukannya.

Pada umumnya rombongan karawitan, menopang diri mereka dengan berbagai macam cara. Cara yang paling lazim adalah konsep kontrak sosial (Brandon, 1989: 360), yakni suatu cara yang mengatur hubungan antara rombongan karawitan dengan penanggapnya. Dasar dari kontrak sosial adalah satu persetujuan untuk memberikan layanan terhadap jasa yang diterima, yang biasanya berupa sejumlah uang kontan. Adapun layanan dari rombongan berupa pergelaran karawitan dengan gending-gending tertentu, yang biasanya repertoar gendingnya diserahkan kepada rombongan itu.

Dukungan bagi rombongan karawitan lazimnya adalah dukungan masyarakat/ komunal. Sebuah rombongan karawitan diminta oleh seseorang atau sebuah organisasi untuk mengadakan pertunjukan dengan jasa yang disepakati atas pertunjukan yang diberikan oleh sponsor bagi masyarakat. Cara kedua yang jarang terjadi atas karawitan adalah dukungan komersial. Masyarakat umum dapat melihat pergelaran karawitan dengan cara membeli tiket sebagai tanda masuk.

Pengaturan perjanjian mengenai besarnya jasa dari penanggap (sponsor) yang harus diterima oleh pimpinan rombongan biasanya diadakan secara lisan, dalam jumlah yang pasti. Setelah usai pertunjukan, pimpinan rombongan baru menerima jasa dari si empunya hajat sesuai kesepakatan di antara mereka berdua. Pembayaran honorarium kepada para pengrawit, pada umumnya memiliki cara yang kurang lebih sama. Lewat seorang pembantu di bidang keuangan, pimpinan rombongan membagikan honorarium semua pembantunya sesuai dengan tanggungjawab masing-masing. Namun demikian ada juga pimpinan rombongan yang memberikan honorarium sendiri kepada semua pembantunya sebelum pertunjukan dimulai, karena pimpinan rombongan juga sudah menerima semua jasa sebelum pertunjukan dimulai. Pergelaran karawitan yang ditopang masyarakat dapat dikaitkan dengan upacara-upacara keagamaan, seperti misalnya khitanan dan pernikahan. Kecuali itu ada yang dikaitkan dengan peringatan

Beberapa Pendekatan Sosiologis Dalam Penelitian Karawitan (T. Slamet Suparno) 
sekuler, seperti hari raya nasional dan peresmian suatu proyek baru. Adapun yang dikaitkan dengan kehidupan pribadi, misalnya hari kelahiran seseorang.

Penonton merupakan elemen paling penting terhadap keberadaan karawitan. Karawitan biasanya merefleksikan penonton, dan penonton merupakan cermin dari karawitan. Tanpa penonton kiranya karawitan tidak akan hidup. Oleh karena itu dapat dikatakan bahwa karawitan dan penonton merupakan belahan-belahan yang bergandengan secara total. Seberapa banyak penonton karawitan, bergantung pada banyak faktor, di antaranya reputasi rombongan, cuaca, jarak lokasi pertunjukan, jenis pesaing, kemampuan finansial penonton, dan waktu pertunjukan.

Rombongan karawitan dengan pengrawit dan suarawati yang mempunyai reputasi bagus, dapat dipastikan jumlah penonton banyak. Demikian pula bila cuaca bagus misalnya tidak turun hujan, biasanya penonton karawitan juga banyak. Namun demikian jika penonton harus mengadakan perjalanan ke lokasi pertunjukan cukup jauh, biasanya mereka malas. Jumlah penonton juga bergantung pada jenis pesaing pertunjukan lain, misalnya di tengah kota yang jenis pertunjukannya bermacam-macam, penonton dihadapkan pada pilihan. Jad penonton akan terdistribusi pada jenis pertunjukan lainnya. Sebaliknya bila pergelaran karawitan dilakukan di pedesaan, tentu saja tidak ada jenis pertunjukan lainnya sebagai pesaing.

Hal lain yang mempengaruhi jumlah penonton adalah kemampuan finansial penonton pada waktu itu untuk membeli tiket bila karawitan dipentaskan di sebuah gedung pertunjukan. Pada musim panen bagi para petani atau sehabis gajian bagi para karyawan, kemungkinan penonton lebih banyak bila dibanding dengan hari-hari lain. Apalagi jika karawitan itu dilakukan pada malam Minggu biasanya penonton akan lebih banyak bila dibandingkan dengan hari lain.

Dari sisi jenis kelamin, laki-laki, perempuan dari berbagai usia, pekerjaan, dan golongan sosial, menyaksikan pergelaran karawitan. Namun demikian, penonton laki-laki biasanya lebih banyak dari pada penonton perempuan. Demikian pula penonton setengah baya dan tua, lebih banyak dari pada penonton muda usia. Rupanya penonton muda usia lebih suka menyaksikan pertunjukan dengan nuansa kontemporer dibandingkan karawitan tradisional. Kanak-kanak dan bayi kadang juga diajak oleh orang tuanya untuk menyaksikan pertunjukan karawitan. Terlebih bila pentas karawitan dilakukan di luar rumah atau di lapangan, mereka datang dan pergi tanpa mengganggu penonton yang lain. Secara global pergelaran karawitan merefleksikan kenyataan bahwa mayoritas penduduk di wilayah kebudayaan Jawa adalah orang desa dengan keadaan ekonomi, pendidikan, dan sosial yang rendah. Biasanya rombongan karawitan lebih banyak pentas di daerah pedesaan.

Imaji, Vol.4, No.2, Agustus 2006 : 154 - 176
Para rombongan karawitan rupanya sadar akan kenyataan bahwa penonton mereka tidak pernah sama pada pertunjukan berikutnya. Penonton yang datang ingin memperoleh kepastian siapa pengrawit dan pesinden yang melaksanakan pertunjukan itu. Bila penonton itu cocok dengan pemain yang sedang melaksanakan pentas, mereka memutuskan untuk tetap melihat pertunjukan itu. Biasanya duapertiga dari penonton meninggalkan tempat pertunjukan setelah menjelang tengah malam. Selebihnya menyaksikan pergelaran itu sampai selesai.

Para penonton dari golongan atas biasanya menyenangi karawitan "klasik" yang mengandung mistik-religius. Tuan rumah dan keluarga dekat serta kerabat-kerabatnya, menyaksikan pertunjukan karawitan dari dalam rumah. Mengingat pentas semacam ini tidak dipungut bayaran, penonton yang hadir mewakili semua usia. Laki-laki dari golongan menengah ke bawah biasanya hadir lebih banyak dibandingkan dengan golongan atas. Penonton akan ikut tepuk tangan dan kadang ikut menyuarakan senggakan bila gending-gending itu bersemangat.

\section{Karawaitan dalam Perspektif Kategori Seni}

Dalam tulisan Hauser (1974: 647) dijelaskan bahwa perubahan sosial di sebuah wilayah akan menghasilkan gaya seni yang khas, sesuai dengan bentuk masyarakat pada waktu itu. Karawitan yang pada periode tertentu merupakan seni tinggi, dapat saja pada periode berikutnya menjadi seni populer, dan bahkan menjadi seni rakyat atau sebaliknya. Tentu saja proses sosio-kultural tidak hanya dipahami sebagai suatu proses reproduksi kebudayaan yang ada, melainkan sekaligus kemungkinan perubahannya. Sebuah kebudayaan tidak begitu saja dengan gampang mengalami perubahan secara cepat tanpa pengaruh ekternal yang sungguh-sungguh besar. Sebuah kebudayaan akan cenderung mempertahankan kesinambungan dalam perubahan, secara transformasional daripada pergantian revolusioner.

Seperti telah diuraikan sebelumnya, bahwa karawitan mempunyai beberapa elemen penting yakni pengrawit, pesindhen, penggerong, peralatan, penanggap dan/atau penonton. Dari sudut pandang strata sosial penonton, Hauser (1974: 6) membuat kategori seni menjadi empat jenis. Pertama, seni tinggi atau klasik yang hanya dinikmati oleh elit kultural, yakni bangsawan, pejabat, pemimpin partai dan sejenisnya. Biasanya elit kultural memiliki tuntutan agar seni mempunyai nilai estetik yang tinggi. Kedua, seni rakyat yang biasanya dinikmati oleh masyarakat pedesaan (agraris). Hanya saja dalam seni rakyat, sulit untuk dipisahkan antara pencipta seni dan penikmat seni. Hal ini mengingat bahwa seni rakyat merupakan hasil kolektif, walaupun pada awalnya seni rakyat itu dihasilkan oleh individu. Dengan kata lain seni rakyat merupakan kreasi individu yang

Beberapa Pendekatan Sosiologis Dalam Penelitian Karawitan (T. Slamet Suparno) 
menjadi milik banyak orang. Biasanya seni rakyat tidak dituntut adanya nilai estetik, karena sifatnya yang spontan. Ketiga, seni populer yang biasa dinikmati oleh masyarakat urban (perkotaan). Jenis seni populer merupakan hiburan bagi masyarakat perkotaan, yang sehari-hari penuh dengan pekerjaan, sehingga kejenuhan akibat kerja keras mereka menuntut adanya hiburan. Biasanya sen populer juga cenderung tidak dituntut nilai estetik, tetapi yang lebih penting adalah rasa relaksasi bagi penikmatnya sehingga mudah untuk dicerna. Keempat, seni massa yang penyajiannya diproduksi oleh alat-alat mekanik (radio, tape player, tv, dll), yang penikmatnya sangat heterogin. Hauser juga menjelaskan bahwa perubahan sosial di sebuah wilayah akan menghasilkan gaya seni yang khas, sesua dengan bentuk masyarakat pada waktu itu. Suatu jenis seni pada periode tertentu merupakan seni tinggi, pada periode berikutnya dapat menjadi seni populer, dan pada periode selanjutnya menjadi seni massa atau sebaliknya.

Rupanya karawitan yang masih hidup dewasa ini adalah karawitan yang termasuk kategori seni klasik, dan seni populer. Karawitan jenis seni klasik yang dulunya berkembang di dalam istana, sejak jaman kemerdekaan telah berkembang sampai ke pedesaan-pedesaan, sehingga karawitan ini masih hidup di perdesaan-pedesaan. Sedangkan karawitan jenis seni populer saat ini masih merebak di perkotaan-perkotaan seperti di Jakarta, Surabaya, Bandung, Semarang, Yogyakarta, Surakarta dan beberapa kota lainnya.

C. Beberapa Pendekatan Sosiologis

1. Fungsionalisme Struktural

Fungsionalisme struktural berpijak dari suatu anggapan bahwa masyarakat bagaikan organisme hidup. Anggapan itu pertama-tama dikembangkan oleh Auguste Comte, kemudian Max Weber, Herbert Spencer Emile Durkheim, Radcliffe-Brown, Malinowski, Parson, dan Robert K. Merton Menururt Weber (Giddens 1985: 184-185), masyarakat merupakan suatu sistem unsur-unsur yang saling bergantung satu dengan yang lain. Fungsionalisme struktural bermanfaat untuk menganalisis struktur masyarakat tertentu.

Herbert Spencer berpendapat bahwa (1) masyarakat atau organisme hidup mengalami pertumbuhan, (2) struktur tubuh sosial maupun organisme hidup mengalami pertumbuhan pula, sehingga semakin besar struktur sosial semakin banyak bagian-bagiannya, (3) setiap bagian yang tumbuh dari organisme sosia maupun organisme biologis mempunyai fungsi dan tujuan tertentu, (4) dalam sistem sosial dan sistem organiseme, setiap perubahan yang terjadi pada suatu bagian akan mengakibatkan perubahan pada bagian lain, dan akhirnya akan mengakibatkan perubahan sistem secara keseluruhan, (5) bagian-bagian itu saling berkait dan merupakan suatu struktur mikro yang dapat dipelajari secara terpisah (Poloma, 1987: 24). Baik Comte maupun Spencer beranggapan bahwa masyarakat dapat dilihat sebagai suatu sistem yang terdiri atas bagain-bagian yang saling bergantung satu dari yang lain (Poloma, 1987: 25).

Durkheim memandang masyarakat sebagai keseluruhan organisme yang mempunyai realitas sendiri. Keseluruhan itu memiliki seperangkat keperluan atau fungsi tertentu yang harus dipenuhi oleh bagian-bagian yang menjadi anggotanya, agar keadaannya tetap normal dan tetap langgeng. Jika keperluan tertentu itu tidak terpenuhi, maka akan berkembang suatu keadaan yang bersifat patologis.

Dalam konteks ini teori fungsional sruktural dapat digunakan untuk menganalisis struktur masyarakat pendukung kehidupan karawitan dan pertunjukan karawitan. Seperti kita ketahui ada beberapa pendukung kehidupan karawitan, di antaranya elit penguasa, lembaga-lembaga pemerintah dan swasta, pengusaha, perorangan, dan lain sebagainya. Struktur dalam pertunjukan karawitan terdiri atas elemen-elemen pengrawit, pesindhen, penggerong, peniti, penyusun gending, penonton, dan penanggap. Elemen-elemen itu saling bekerja sama mendukung keberhasilan suatu pertunjukan karawitan. Jika salah satu elemen tidak berfungsi, dapat saja pergelaran karawitan tidak berhasil. Demikian pula repertoar gending dan/atau urutan gending yang disajikan, juga merupakan struktur pertunjukan karawitan yang dapat dianalisis dengan teori ini. Pemilihan repertoar dan/atau urutan sajian gending, akan mempengaruhi keberhasilan pergelaran karawitan. Pemilihan repertoar gending dan begitu juga urutan sajian akan memberikan apresiasi yang sekaligus sesuai dengan level kejiwaan penonton yang akan menyaksikan pergelaran karawitan itu. Penonton usia anak-anak, remaja, dan pemuda pada umumnya, pasti tidak akan dapat mengapresiasi repertoar gending klasik. Penonton yang berada di luar budaya karawiatn tentu saja memerlukan waktu untuk dapat mengapresiasi karawitan. Banyak hal yang dapat dianalisis mengenai pergelaran karawiatan dari sudut pandang teori ini.

2. Interaksi Simbolik

Teori terpenting dalam interaksi simbolik adalah teori George Herbert Mead, yang pada dasarnya ia menyetujui keunggulan dunia sosial, dalam arti bahwa dunia sosial itulah muncul kesadaran, pikiran, dst. Unit paling mendasar dalam teori sosial Mead adalah tindakan, meliputi empat tahap yang berhubungan secara dialektis yakni: impuls, persepsi, manipulasi, dan konsumasi (Ritzer dan Goodman, 2003:318). Tindakan sosial melibatkan dua orang atau lebih dan mekanisme dasar tindakan sosial adalah isyarat. Manusia memiliki kemampuan untuk menciptakan isyarat yang berkaitan dengan suara, kemampuan itu menghasilkan kemampuan khusus untuk memakai simbol signifikan. Simbol signifikan menghasilkan pengembangan bahasa dan kemampuan khusus untuk berkomunikasi satu sama lain. Simbol signifikan juga membuka peluang untuk berpikir maupun berinteraksi dengan simbol-simbol.

Beberapa Pendekatan Sosiologis Dalam Penelitian Karawitan (T. Slamet Suparno) 
Interaksi simbolik dapat diringkas dengan prinsip dasar seperti berikut: Manusia dibekali kemampuan berpikir

- Kemampuan berpikir dibentuk oleh interaksi sosial.

- Dalam interaksi sosial, manusia mempelajari makna dan simbol yang memungkinkan mereka menggunakan kemampuan berpikir mereka.

- Makna dan simbol memungkinkan manusia melakukan tindakan khusus dan berinteraksi.

- Manusia mampu mengubah arti dan simbol yang mereka gunakan dalam tindakan dan interaksi berdasarkan penafsiran mereka terhadap situasi.

- Manusia mampu memodifikasi dan mengubah, sebagian karena kemampuan mereka berinteraksi dengan diri mereka sendiri, yang memungkinkan mereka menguji serangkaian peluang tindakan, menilai keuntungan dan kerugian relatifnya dan kemudian memilih satu di antara serangkaian peluang tindakan itu.

- Pola aksi dan interaksi yang saling berkaitan akan membentuk kelompok dan masyarakat (Ritzer dan Goodman, 2003:319).

Menurut Blumer, ada tiga pokok pikiran interaksi simbolik, yakni: (1) manusia bertindak (act) terhadap sesuatu atas dasar makna (meaning), (2) makna itu berasal dari interaksi sosial seseorang dengan sesamanya, (3) makna itu diperlakukan atau diubah melalui sutu proses penafsiran, yang digunakan orang dalam menghadapi sesuatu yang dijumpainya (Poloma, 1987:216; Basrowi dan Sukidin, 2002:116). Proses penyampaian makna inilah yang merupakan poko kajian dari kaum interaksionisme simbolik.

Sementara itu Paul Johnson memandang teori interaksi simbolik lebih pada sisi proses komunikasi (Basrowi dan Sukidin, 2002:118). Dalam komunikasi ada dua hal penting yakni isyarat dan simbol, yang kemudian diperlukan proses pemikiran dalam menggunakan dan menerjemahkan simbol-simbol itu. Sebagai salah satu simbol yang terpenting dalam interaksi simbolik yakni bahasa dan isyarat. Simbol merupakan suatu proses penyampaian makna, dan hal inilah yang menjadi subject matter dalam interaksi simbolik.

Adapun asumsi-asumsi interaksi simbolik dari Blumer adalah sebagai berikut: (1) Manusia bertindak terhadap sesuatu berdasar makna-makna yang dimiliki benda itu bagi mereka, dalam arti bahwa interaksi antar manusia dijembatani oleh penggunaan simbol-simbol, penafsiran, dan oleh kepastian makna dari tindakan-tindakan orang lain; (2) Makna-makna itu merupakan hasil interaksi sosial dalam masyarakat; (3) Makna-makna itu dimodifikasikan melalui suatu proses penafsiran yang digunakan oleh setiap individu dalam keterlibatannya dengan tanda-tanda yang dihadapinya. Pada hakekatnya, interaksi simbolik berlangsung di antara berbagai pemikiran dan makna yang menjadi

Imaji, Vol.4, No.2, Agustus $2006: 154$ - 176 karakter masyarakat. Dalam interaksi simbolik, kedirian individual (oneself) dan masyarakat sama-sama merupakan aktor. Individu dan masyarakat merupakan unity yang tidak dapat dipisahkan, keduanya saling menentukan satu dengan lainnya.

Dalam konteks penelitian karawitan, konsep interaksi simbolik dapat digunakan untuk menganalisis makna hubungan antara pengrawit, pesindhen, penggerong dengan penonton. Sebagai contoh kecil dapat dilihat dalam kasus pertunjukan karawitan pada saat penonton turut tepuk tangan (keplok), mengangguk-angguk (manggut-manggut) merespon atas sajian gending para pengrawit, penggerong dan pesindhen. Berarti bahwa penonton merespon secara positif atas sajian gending-gending yang didengarkan. Boleh jadi penonton ikut menangis pada saat disajikan gending-gending yang berkarakter sedih, dan sebagainya. Bahkan kadang ada penonton yang ingin melantunkan tembang (misalnya bawa atau palaran), yang dapat dimaknai bahwa ia tertarik atas pergelaran karawitan itu.

3. Fenomenologi

Suatu fenomena yang tampak sebenarnya refleksi realitas yang tidak berdiri sendiri, karena yang tampak adalah obyek yang penuh makna yang transendental. Oleh karena itu, untuk memperoleh kebenaran, harus menerobos melampaui fenomena yang tampak itu (Waters, 1994:31). Pandangan ini disempurnakan Schutz dengan menggabungkan fenomena transendental dari konsep Husser dan konsep verstehen Weber. Schutz berpendapat bahwa dunia sosial keseharian merupakan suatu yang inter-subyektif dan pengalaman penuh makna (Waters, 1994:234).

Fenomenologi berusaha memahami pemahaman informan terhadap fenomena yang muncul dan kesadarannya, serta fenomena yang dialami informan dan dianggap sebagai entitis sesuatu yang ada dalam dunia (Collin, 1997:115). Fenomenologi tidak pernah berusaha mencari pendapat dari informan apakah sesuatu itu benar atau salah, namun fenomenologi berusaha mereduksi kesadaran informan dalam memahami fenomena itu. Oleh karena itu, fenomenologi menggunakan instrumen yang disebut verstehen, untuk menggambarkan secara detail mengenai bagaimana kesadaran itu berjalan dengan sendirinya. Dalam menggunakan alat verstehen itu, peneliti harus masuk dalam pikiran informan. Oleh sebab itu, fenomenologi menggunakan metode kualitatif dengan melakukan pengamatan partisipan, wawancara intensif, melakukan analisis terhadap kelompok kecil, dan memahami kelompok sosial.

Perspektif fenomenologi pengembangan Berger lebih diarahkan untuk melihat makna-makna yang berkembang di luar makna umum, karena ia berpendapat bahwa manusia memiliki naluri-naluri yang relatif stabil dan bersifat

Beberapa Pendekatan Sosiologis Dalam Penelitian Karawitan (T. Slamet Suparno) 
khusus (Berger 1987:21-76). Menurut Berger, makna yang berkembang dalam organisasi sosial mengalami obyektifikasi dalam institusi-institusi sosial. Nilainilai kultural, ide-ide, dan norma-norma dilihat sebagai pusat organisasi sosial yang di dalamnya anggota-anggota baru disosialisasikan. Akan tetapi, Berger menempatkan perkembangan nilai dan norma di luar interaksi sosial dari individu-individu. Fenomenologi menempatkan tindakan dalam pikiran.

Menurut Berger, individu bertindak secara praktis atas dasar pilihan rasional, bahwa pemahaman terhadap tindakan seseorang tidak hanya berasal dari pengaruh dalam dirinya sendiri, melainkan juga merupakan produk dari kesadarannya terhadap orang lain. Setiap tindakan manusia dilakukan secara dialektis dalam dan bagi dirinya sendiri, serta dalam dirinya dengan kondisi masyarakat di sekitarnya. Masyarakat adalah produk dari individu (eksternalisasi) dan sebaliknya, lalu masyarakat mempengaruhi kembali individu itu (internalisasi) (Berger, 1994:210). Dalam pemahaman ini, Berger menempatkan subyek yang diteliti sebagai subyek yang kritis dan problimatik, dalam arti bahwa perlu menyertakan pengetahuan yang dimiliki oleh subyek yang diteliti.

Hal yang ingin diketahui Berger adalah pengetahuan umum mengenai kehidupan sehari-hari, cara masyarakat mengorganisir pengalamannya, dan secara khusus mengenai dunia sosialnya. Pembahasan Berger mengenai fenomenologi ditekankan pada interaksi antar individu. Ia menekankan bahwa aktor memiliki makna subyektif, aktor rasional dan bebas, dan tidak ditentukan secara mekanik. Aktivitas manusia harus dipahami sebagai sesuatu yang bermakna bagi aktor dalam masyarakat. Oleh karena itu, setiap aktivitas harus diinterpretasikan (Berger, 1987:71)

Ada dua varian fenomenologi, yakni fenomenologi hermenuetik dan fenomenologi eksistensial (Berger, 1987:71). Fenomenologi hermenuetik terfokus pada aspek kolektif dari budaya yang perhatiannya pada bahasa. Teks dapat dianalisis secara obyektif, dalam arti mengeksplorasi dan menentukan kealamiahan serta struktur komunikasi. Sedangkan fenomenologi eksistensial, berorientasi pada level individu dari budaya yang meliputi internalisasi kesadaran subyektif dari individu. Setiap fenomenologi dapat dideskripsikan sebagai sesuatu yang empirik dan terkait dengan kehidupan sehari-hari.

Dalam konteks ini, konsep fenomenologi dapat digunakan untuk menganalisis fenomena sosial yang terefleksikan di dalam teks vokal karawitan. Banyak fenomena sosial yang tercermin dalam teks vokal karawitan, misalnya teks gerongan ketawang Puspogiwang, laras pelog patet barang, yakni Parabe sang Marabangun, dst. Teks itu menggambarkan "pertengkaran" antara seorang laki-laki dan seorang perempuan mengenai karakter masing-masing. Fenomenologi juga dapat untuk menganalisis kebiasaan-kebiasaan hidup sehari-

Imaji, Vol.4, No.2, Agustus 2006 : 154 - 176 hari para pelaku karawitan yang tercermin dalam berolah karawitan. Misalnya kebiasaan minum minuman keras (alkoholic), yang dibawa ke dalam kegiatan berkarawitan. Kepada informan tidak akan ditanyakan apakah tindakan minum minuman keras itu salah atau benar, melainkan fenomenologi akan berusaha mereduksi kesadaran informan dalam memahami fenomena minum minuman keras. 4. Neofungsionalisme

Neofungsionalisme yang digagas Alexander dan Colomy merupakan pengembangan dari teori sistem atau fungsionalisme-struktural yang dihasilkan Parson dan kemudian Merton muridnya. Alexander (1985:10; periksa Ritzer dan Goodman, 2003:148) menyebut problem yang diasosiasikan dengan fungsionalisme-sruktural yang perlu diatasi oleh neofungsionalisme, termasuk anti-individualisme, antagonistik terhadap perubahan, konservatisme, idealisme, dan bias antiempiris.

Alexander menguraikan beberapa orientasi dasar neofungsionalisme sebagai berikut. Pertama, neofungsionalisme bekerja dengan model masyarakat deskriptif. Model ini melihat masyarakat tersusun dari unsur-unsur yang saling berinteraksi menurut pola tertentu. Pola ini memungkinkan sistem dibedakan dari lingkungannya. Kedua, Alexander menyatakan bahwa neofungsioanalisme memusatkan perhatian yang sama besarnya terhadap tindakan dan keteraturan. Perspektif ini memberikan perhatian yang cukup terhadap pola tindakan di tingkat yang lebih mikro, dan tidak hanya tindakan yang rasional tetapi juga yang ekspresif. Ketiga, neofungsionalisme memperhatikan masalah integrasi, namun bukan dilihat sebagai fakta sempurna melainkan lebih dilihat sebagai kemungkinan sosial. Neofungsionalisme mengakui bahwa penyimpangan dan kontrol sosial adalah realitas dalam sistem sosial. Keempat, neofungsionalisme tetap menerima Parsonsian tradisional atas kepribadian, kultur, dan sistem sosial. Selain sebagai aspek vital untuk struktur sosial, interpenetrasi atas sistem sosia itu juga menghasilkan ketegangan yang merupakan sumber perubahan. Kelima, neo-fungsionalisme memusatkan pada perubahan sosial dalam proses diferensiasi di dalam sistem sosial, kultural, dan kepribadian. Perubahan tidak hanya menghasilkan keselarasan dan konsensus, namun juga dapat menimbulkan ketegangan, baik individual maupun kelembagaan. Terakhir, neofungsionalisme secara tak langsung menyatakan komitmennya terhadap kebebasan dalam mengkonseptualisasikan dan menyusun teori.

Konsep neofungsionalisme dapat digunakan untuk menganalisis perubahan garap karawitan karena adanya perubahan sosial. Perubahan sosial dapat menyebabkan perubahan nilai atau norma yang berlaku di masyarakat. Oleh karena itu perubahan nilai juga dapat menyebabkan perubahan garap karawitan. Sebagai contoh, garap karawitan gaya Surakarta pada beberapa dekade yang lalu 
terasa mengalir dalam aspek volume maupun aspek irama. Perubahan keras lirihnya tabuhan dilakukan secara mengalir dari lirih, sidikit keras, keras, kembali ke sedikit keras terus akhirnya menuju lirih. Demikian juga perubahan kecepatan (irama) tabuhan, dimulai dari lambat, agak cepat, cepat, kembali ke agak cepat, dan akhirnya menuju ke lambat. Jika perubahan itu dilakukan secara mendadak, rasa karawitan akan dirasakan nggronjal dan tidak enak. Namun demikian, dengan berjalannya waktu terjadi perubahan nilai, bahwa perubahan mengalir terasa sudah tidak sesuai dengan nilai jaman yang serba cepat. Dengan demikian perubahan mendadak akhirnya dirasakan enak oleh kalangan pengrawit.

\section{Teori Konflik}

Teori konflik sebagian berkembang sebagai reaksi terhadap fungsionalisme-struktural dan neofungsionalisme. Teori konflik yang akan diuraikan dalam paper ini adalah karya Ralf Dahrendorf (Ritzer dan Goodman, 2003:153-157). Menurut Dahrendorf, setiap masyarakat setiap saat tunduk pada proses perubahan. Fungsionalis menekankan keteraturan masyarakat, sedangkan teori konflik melihat pertikaian dan konflik dalam sistem sosial. Fungsionalis menyatakan bahwa setiap elemen masyarakat berperan dalam menjaga stabilitas, sedangkan teoritisi konflik melihat berbagai elemen kemasyarakatan menyumbang terhadap disintegrasi dan perubahan. Fungsionalis cenderung melihat masyarakat secara informal diikat oleh norma, nilai dan moral. Teoritis konflik melihat apa pun keteraturan yang terdapat dalam masyarakat berasal dari pemaksaan terhadap anggotanya oleh mereka yang berada di atas. Fungsionalis memusatkan perhatian pada kohesi yang diciptakan oleh nilai bersama masyarakat. Teoritisi konflik menekankan pada peran kekuasaan dalam memperhatikan ketertiban dalam masyarakat. Menurut teori konflik, masyarakat ditentukan oleh ketidakbebasan yang dipaksakan Dengan demikian posisi tertentu di dalam masyarakat mendelegasikan kekuasaan dan otoritas terhadap posisi yang lain. Menurut Dahrendorf, tugas pertama analisis konflik adalah mengidentifikasi berbagai peran otoritas di dalam masyarakat tertentu.

Konsep kunci lain dalam teori konflik Dahrendorf yakni kepentingan. Dalam setiap asosiasi, orang yang berada pada posisi dominan berupaya mempertahankan status quo, sedangkan orang yang berada pada posisi subordinat berupaya mengadakan perubahan. Konflik kepentingan di dalam asosiasi selalu ada sepanjang sejarah. Hal itu berarti bahwa legitimasi otoritas selalu terancam. Dahrendorf melihat analisis hubungan antara kepentingan tersembunyi dan kepentingan nyata sebagai tugas utama teori konflik.

Selanjutnya Dahrendorf membedakan tiga tipe utama kelompok, yakni kelompok sетu atau sejumlah pemegang posisi dengan kepentingan yang sama, yang merupakan calon anggota tipe kedua, yakni kelompok kepentingan, yang

Imaji, Vol.4, No.2, Agustus $2006: 154$ - 176 merupakan agen riil dari konflik kelompok. Dari berbagai jenis kelompok kepentingan itulah muncul kelompok konflik yakni kelompok yang terlibat dalam konflik kelompok aktual. Menurut Dafrendorf, konsep kepentingan tersembunyi, kepentingan nyata, kelompok semu, kelompok kepentingan, dan kelompok konflik adalah konsep dasar untuk menjelaskan konflik sosial. Segera setelah konflik muncul, kelompok itu melakukan tindakan yang menyebabkan perubahan dalam struktur sosial. Jadi konflik juga menyebabkan perubahan dan perkembangan.

Teori konflik yang lebih sintesis dan integratif muncul kemudian adalah karya Randall Collins (Ritzer dan Goodman, 2003:160). Karya Kollins (1975) berjudul Conflict Sociology, sangat integratif karena jauh lebih berorientasi mikro ketimbang teori konflik makro Dahrendorf. Collins (1990:72). mengatakan bahwa kontribusi utama untuk teori konflik adalah menambah analisis tingkat mikro terhadap teori yang bertingkat makro. Ia menunjukkan bahwa stratifikasi dan organisasi didasarkan atas interaksi kehidupan sehari-hari. Collins mendekati konflik dari sudut pandang individu karena akar teoritisnya terletak dalam fenomenologi dan etnometodologi. Namun demikian dia sadar bahwa sosiologi tidak akan berhasil hanya berdasarkan analisis tingkat mikro saja. Dengan demikian, teori konflik tidak dapat bekerja tanpa teori kemasyarakatan.

Collins (1975:49) memilih memusatkan perhatian pada stratifikasi sosial, karena stratifikasi sosial merupakan institusi yang menyentuh begitu banyak ciri kehidupan, seperti kekayaan, karier, keluarga, klub, komunitas, gaya hidup. Collins bertolak dari beberapa asumsi, orang dipandang mempunyai sifat sosial, namun juga terutama mudah berkonflik dalam hubungan sosial mereka. Konflik mungkin terjadi dalam hubungan sosial karena penggunaan kekerasan yang selalu dapat dipakai seseorang atau banyak orang dalam lingkungan pergaulan. Ada tiga prinsip pendekatan konflik terhadap stratifikasi sosial. Pertama, Collins yakin bahwa orang hidup dalam dunia subyektif yang dibangun sendiri. Kedua, orang lain memiliki kekuasaan untuk mempengaruhi pengalaman subyektif seseorang individu. Ketiga, orang lain mencoba mengontrol orang yang menentang mereka.

Atas dasar pendekatan itu, Collins mengembangkan lima prinsip analisis konflik yang diterapkan terhadap stratifikasi sosial. Pertama, teori konflik harus memusatkan perhatian pada kehidupan nyata. Ia menyarankan agar kita memikirkan bahwa tindakan manusia dimotivasi oleh kepentingan diri sendiri, untuk mencapai keuntungan sehingga dia dapat mencapai kepuasan dan menghindari ketidak puasan. Kedua, teori konflik terhadap stratifikasi sosial harus meneliti susunan material yang mempengaruhi interaksi. Aktor yang memiliki sumber daya materia banyak dapat menentang hambatan material, namun aktor dengan sumber daya lebih sedikit, akan bertindak sesuai keadaan material mereka.

Beberapa Pendekatan Sosiologis Dalam Penelitian Karawitan (T. Slamet Suparno) 
Ketiga, dalam situasi ketimpangan, kelompok yang mengendalikan sumber daya akan mencoba mengekploitasi kelompok yang sumber dayanya terbatas. Keempat, teoritisi konflik sebaiknya melihat fenomena kultural seperti keyakinan dan gagasan dari sudut pandang kepentingan, sumber daya, dan kekuasaan. Kelima, dia mempunyai komitmen tegas untuk melakukan studi ilmiah mengenai stratifikasi dan setiap aspek kehidupan sosial lainnya. Dengan demikian sosiolog perlu meneliti stratifikasi secara empiris dan jika perlu secara komparatif Akhirnya sosiolog harus mencari penyebab fenomena sosial, terutama berbagai penyebab setiap bentuk perilaku sosial.

Teori konflik dalam konteks paper ini dapat digunakan untuk menganalisis perubahan kehidupan karawitan dari kurun waktu yang satu ke kurun waktu berikutnya. Mengapa karawitan selalu berkembang? Dari sudut pandang teori konflik hal itu dikarenakan adanya kepentingan para penguasa dan/atau individu (patron) yang memiliki kekuasaan. Sebagai contoh, kehidupan karawitan pada jaman kolonial, cenderung dipengaruhi oleh raja yang berkuasa saat itu. Karawitan lebih banyak digunakan sebagai alat kelengkapan upacara. Pada jaman revolusi atau awal kemerdekaan, karawitan cenderung sebagai alat pemersatu bangsa. Pada jaman sebelum era Orde Baru, karawitan cenderung sebagai alat propaganda partai. Pada era Orde Baru, karawitan lebih cenderung sebagai propaganda program-program pembangunan dan sekaligus sebagai kritik sosial. Oleh karena itu, dalam setiap kurun waktu tampak bahwa karawitan sebagai hayatan sangat tipis kadarnya, dan sebalikya karawitan sebagai fungsi sosial sangat dominan.

\section{Dramaturgi}

Menururt Goffman dalam bukunya berjudul The Presentational of Self in Everyday Life, perilaku orang dalam interaksi sosial selalu melakukan permainan informasi agar orang lain mempunyai kesan yang lebih baik. Kesan non-verbal inilah yang perlu dicek keasliannya. Dalam konsep ini, Goffman memfokuskan pada ungkapan yang lebih bersifat teateris, kontekstual, nonverbal, dan tidak bersifat intensional. Dalam konteks analisis, orang akan lebih berusaha untuk memahami makna untuk mendapatkan kesan dari berbagai tindakan orang lain, baik yang tercermin dari mimik wajah, isyarat, dan kualitas tindakan. Semua itu menurut Goffman memiliki keakuratan yang lebih dibandingkan dengan ungkapan verbal.

Salah satu konsep yang dibangun Goffman adalah dramaturgi. Konsep ini dibangun sebagai kritik atas fungsionalisme struktural. Dramatrugi mencoba mempertanyakan mengapa individu harus diperlakukan sebagai pemeran yang harus memainkan semua peran yang telah ditetapkan oleh struktur. Mengapa peran yang dimainkan oleh individu ketika di panggung depan berlainan dengan apa

Imaji, Vol.4, No.2, Agustus 2006 : 154 - 176 yang dimainkan di panggung belakang, dan mengapa ada dua panggung dalam kehidupan.

Di arena panggung depan, individu akan menunjuk sosok ideal (penampilan sesuai dengan tuntutan status sosialnya), sedangkan panggung belakang merupakan bagian penampilan individu tempat manaia dapat menyesuaikan diri dengan situasi penontonnya. Dalam kegiatan rutin individu memerlukan sejumlah individu lain untuk bekerja sama menampilkan perannya. Untuk menjaga kelancaran kerja sama itu, maka setiap anggota team harus percaya tindakan temannya dan mampu menghentikan pertunjukan jika terjadi penyimpangan. Jika terjadi krisis di arena panggung penampilan, maka untuk menjaga kelangsungan pertunjukan, diperlukan team yang memiliki atribut langkah bertahan oleh pelaku, dan langkah pencegahan oleh penonton. Kecuali itu diperlukan kemampuan pelaku untuk memotivasi penonton agar mereka mau mengambil langkah-langkah pencegahan.

Dalam konteks pertunjukan karawitan Sragenan dan/atau karawitan Campursari, konsep dramaturgi dapat dimanfaatkan untuk menganalisis tindakan negatif para pelaku petunjukan, baik pengrawit, pesindhen, terutama penonton atas dasar perilaku non-verbalnya. Sebagai contoh kasus pertunjukan klenengan Sragenan, misalnya pada saat para penonton "menari" mengikuti ritme kendang gaya Sragenan, di antara mereka ada yang marah-marah karena tersenggol api rokok yang dipegang sesama "penari". Pertanyaan yang perlu ditelusuri jawabannya yakni mengapa perilaku penonton seperti itu dan apakah perilaku itu menggambarkan karakter individu yang sesungguhnya.

\section{Perubahan Sosial}

Perubahan sosial merupakan sebuah konsep yang menunjuk kepada perubahan fenomena sosial di berbagai tingkat kehidupan, mulai dari tingkat individu sampai tingkat sosial, dan juga mencakup perubahan struktur sosial (Lauer, 1989: 4-5). Segala sesuatu mengalami perubahan, tidak hanya sesuatu yang bergerak, namun juga sesuatu yang tetap. Perubahan sosial juga terjadi dalam kehidupan tradisional terlebih dalam kehidupan modern.

Perubahan sosial ada yang disengaja menyangkut hal-hal yang positip, dan ada yang tidak disengaja menyangkut hal-hal yang negatip (Lauer, 1989: 17). Halhal yang positip misalnya perubahan dari tidak tahu menjadi tahu, dan dari miskin menjadi kaya. Hal-hal yang bersifat negatip misalnya perubahan dari sehat menjadi sakit, dari kaya menjadi miskin, dan dari keadaan damai menjadi kacau. Tingkat perubahan yang terjadi secara cepat dapat menimbulkan ketegangan yang sangat besar (Lauer, 1989: 16). Perubahan sosial dapat terjadi karena adanya penggerak yang berasal dari dalam dan dari luar. Penggerak perubahan yang berasal dari dalam misalnya sikap masyarakat terhadap penemuan baru, sikap

Beberapa Pendekatan Sosiologis Dalam Penelitian Karawitan (T. Slamet Suparno) 
masyarakat untuk maju, dan sikap keterbukaan masyarakat terhadap perubahan Penggerak perubahan dari luar misalnya pengaruh pergaulan dengan dunia luar, pengaruh kebudayaan asing, dan lain sebagainya.

Ada beberapa faktor yang menghambat proses perubahan sosial, seperti ditulis oleh Lauer (1989: 12-13), di antaranya (1) sifat traumatis atas perubahan yang didukung oleh sejumlah rintangan sosial dan psikologis terhadap perubahan yang telah diketahui; (2) sikap tradisional masyarakat yang tidak mengerti akan makna perubahan; (3) sistem stratifikasi sosial yang kaku, ketimpangan sosial, kepentingan terselubung; dan (4) sikap ketidakpercayaan masyarakat terhadap perubahan yang diperkirakan akan merugikan.

Dalam konteks perubahan karawitan dapat dipengaruhi adanya perubaha sosial seperti telah dijelaskan sebelumnya. Sebagai contoh sederhana misalnya mengapa jumlah dan jenis perangkat klenengan saat ini mengalami perubahan, karena penonton menuntut adanya suasana yang lebih meriah, seru, dan gebyar. Jika dibandingkan dengan perangkat klenengan pada tigapuluh tahun yang lalu, jumlah dan jenis perangkat klenengan saat ini lebih banyak jumlah dan jenisnya, seperti misalnya adanya penambahan keyboard, jumlah kenong lebih banyak, jumlah kempuil lebih banyak, dan jumlah balungan lebih banyak. Kemungkinan juga pola-pola tabuhan ricikan garap lebih banyak setelah menerima pengaruh dari pola-pola tabuhan jenis karawitan etnis lain. Demikian pula pola garap karawitan yang menyangkut berbagai aspek karawitan, seperti cengkok, irama, keras lirih tabuhan dapat dianalisis dengan teori perubahan sosial.

8. Analisis Wacana

Analisis wacana merupakan model analisis yang paling kontempore dibandingkan model-model analisis lainnya. Eksistensinya dapat disebut sebagai generasi berperspektif post-modernisme, beroperasi dengan sejumlah asumsi yang sangat berbeda, dan bahkan bertentangan dengan metode konvensional kuantitatif. Istilah wacana menurut Muhaimin, seperti dikutip oleh Basrowi dan Sukidin (2002: 229), merupakan kemampuan untuk maju menurut urut-urutan yang teratur dan semestinya serta merupakan komunikasi buah pikiran, baik lisan maupu tulisan yang resmi dan teratur. Sementara itu Tarigan, sperti juga dikutip oleh Basrowi dan Sukidin (2002: 229), berpendapat bahwa istilah wacana mencakup percakapan, obrolan, pembicaraan di muka umum, tulisan, dan upaya-upaya formal seperti laporan ilmiah dan sandiwara atau lakon

Didasarkan atas kedua pendapat itu, Sobur (2001: 11), seperti juga diuraikan oleh Basrowi dan Sukidin (2002: 229), menyatakan bahwa wacana merupakan rangkaian ujar atau rangkaian tindakan tutur yang mengungkapkan sesuatu hal yang disajikan secara teratur, sistematis, dalam suatu kesatuan yang koheren, dibentuk oleh unsur segmental maupun non segmental bahasa. Dalam

Imaji, Vol.4, No.2, Agustus 2006: 154 - 176 bukunya itu, Sobur mengutip pendapat Foucault bahwa wacana dapat dibedakan menjadi tiga macam, yakni wacana dari level konseptual teoritis, konteks penggunaan, dan metode penjelasan. Didasarkan atas level konseptual teoritis, wacana diartikan sebagai domain umum atas semua pernyataan, yakni semua ujaran atau teks yang memiliki makna dan efek dalam dunia nyata. Dalam konteks penggunaannya, wacana berarti sekumpulan pernyataan yang dapat dikelompokkan ke dalam kategori konseptual tertentu. Pengertian ini menekankan pada upaya untuk mengidentifikasi struktur tertentu dalam wacana, yakni kelompok ujaran yang diatur dengan suatu cara tertentu. Didasarkan atas metode penjelasannya, wacana merupakan suatu praktik yang diatur untuk menjelaskan sejumlah pernyataan.

Berdasarkan saluran yang digunakan dalam berkomunikasi, wacana dibedakan menjadi dua jenis, yakni wacana tulis dan wacana lisan (Arifin dan Rani, 2000: 22-39). Berdasarkan atas jumlah peserta yang terlibat dalam pembicaraan dalam komunikasi, terdapat tiga jenis wacana, yakni monolog, dialog, dan polilog. Didasarkan atas tujuan berkomunikasi, dikenal wacana deskripsi, eksposisi, argumentasi, persuasi, dan narasi. Analisis wacana lahir dari kesadaran bahwa permasalahan yang ada dalam komunikasi tidak hanya terbatas pada penggunaan kalimat, bagian kalimat, atau fungsi ucapan, namun juga mencakup strutur pesan yang lebih komplek dan inheren.

Bagaimana analisis wacana bekerja, berikut uraian Sparingga (2000: 3 ) yang dirangkum oleh Basrowi dan Sukidin (2002: 235).

1. Bahasa, kalimat, kata-kata, baik lisan maupun tertulis merupakan sebuah wacana.

2. Analisis wacana selalu memperhatikan bagaimana sebuah kata itu diproduksi dalam sebuah konteks tertentu, yang merupakan jaringan bermakna.

3. Dari penjelasan kedua butir tersebut di atas, menegaskan bahwa

a. bagaimana analisis wacana memperlakukan bahasa sebagai bagian dar praktik sosial dan bukan semata-mata representasi aktivitas individual.

b. terdapat hubungan dialektis antara wacana dan struktur sosial sebagaimana hubungan praktik sosial dan struktur sosial.

c. wacana dibentuk dan dikendalikan oleh struktur sosia

d. wacana selalu melibatkan proses formasi obyek, subyek dan konsep yang secara dialektis membuat realitas menjadi bermakna

4. Terdapat tiga hal penting dalam analisis wacana, yakni

a. memberikan perhatian pada usaha mengidentifikasi identitas sosial dan posisi subyek

b. membantu usaha mengkonstruksikan hubungan sosial di antara individu 
c. memberikan alat untuk mengkonstruksikan sistem pengetahuan dan kepercayaan.

Dalam konteks penelitian karawitan, analisis wacana dapat diterapkan pada pembicaraan-pembicaraan lisan maupun tertulis tentang karawitan. Tulisan berupa buku, paper, artikel dan sejenisnya dapat menjadi bahan kajian dengan menggunakan teori analisis wacana. Cakepan yang disajikan pesindhen, penggerong, penari, dan dalang merupakan sebuah karya tulis (teks) yang dapa dimaknai sesuai dengan konteks sosial yang berlaku pada saat teks itu dibuat. Demikian pula pembicaraan para pelaku karawitan, baik itu berupa monolog, dialog, atau polilog dapat dimaknai dalam konteks sosial tertentu.

Sebagai contoh salah satu karya sastra Mangkunagara IV berjudu Tripama, ditulis dalam bentuk tembang macapat Dhandhanggula, yang sering dimanfaatkan dalam pertunjukan karawitan. Dalam tembang yang terdiri atas tujuh bait itu, konsep satria dapat dimaknai seperti berikut. Dalam konteks yang berbeda-beda, konsep satria tercermin dalam tindakan tiga tokoh wayang, yakn Sumantri, Kumbakarna, dan Karna. Kesetiaan Sumantri terhadap Suwonda, Kumbakarna membela negaranya, dan Karna membalas budi rajanya, akhirnya ketiganya gugur di medan perang. Mereka melaksanakan tugas sebagai prajurit, dan menepati janji sesuai dengan apa yang diucapkannya.

\section{Penutup}

Karawitan merupakan salah satu jenis (genre) seni pertunjukan Jaw tradisional, memiliki beberapa elemen meliputi rombongan/group (pengrawit, pesindhen/suarawati), peralatan (gamelan), penanggap dan/atau penonton. Karawitan secara tradisi menggunakan seperangkat gamelan laras slendro dan pelog yang sebagian besar terdiri atas instrumen pukul (perkusi) dari perunggu dan sebagian kecil instrumen gesek, tiup, dan petik.

Pada prinsipnya, karawitan merupakan salah satu wujud fenomena sosial yang ada di masyarakat. Sebagai wujud fenomena sosial, tentu saja karawitan akan mengalami perkembangan sejalan dengan perkembangan masyarakat. Pada sisi lain, karawitan juga dapat dijadikan sebagai fokus kajian dalam kegiatan penelitian ilmiah. Sesuai dengan prinsip dasar di atas, yakni karawitan sebagai fenomena sosial, kegiatan penelitian juga dapat menggunakan pendekatan berbagai disiplin ilmu sosial, khususnya sosiologi.

\section{DAFTAR PUSTAKA}

Arifin, Bustanul dan Abdul Rani, 2000. Prinsip-Prinsip Analisis Wacana. Jakarta: Depdiknas, Dikti, Direktorat P3M.

Basrowi dan Sukidin, Metode Penelitian Kualitatif, Perspektif Mikro. Surabaya: Insan Cendekia.

Imaji, Vol.4, No.2, Agustus 2006: 154 - 176
Berger, L. Peter, dkk., Cultural Analysis. London and New York: Routledge and Kegan Paul.

Berger, L. Peter \& Thomas Luckman, 1994. Tafsir Sosial Atas Kenyataan. Terj. Hasan Basri dari The Social Construction of Reality. Jakarta: LP3ES.

Brandon, James R., 1967. Theatre in Southeast Asia. Cambridge, Massachusetts: Harvard University Press.

Collin, Finn, 1997. Social Reality. USA and Canada: Routledge Simultaneously Published.

Collins, Randall, 1975. Conflict Sociology: Toward an Explanatory Science. New York: Academic Press.

Leauer, Robert H., 1982. Perspectives on Social Change. Boston: Allyn and Bacon Inc.

Poloma, Margaret M., (ed.), 1994. Sosiologi Kontemporer. Jakarta: Raja Grafindo Persada.

Ritzer, George, 2000. Sociological Theory. New York, singapore: McGraw-Hill Ritzer, George \& Goodman, Douglas J., 2003. Teori Sosiologi Modern. Terj. Alimandan. Jakarta: Prenada Media.

Sobur, Alex, 2001. Analisis Teks Media. Bandung: Remaja Rosda Karya.

Kayam, Umar, 2001. Kelir Tanpa Batas. Yogyakarta: Gama Media.

Waridi, 1997. "RL. Martapangrawit, Empu Karawitan Gaya Surakarta Sebuah Biografi”, Tesis S-2 Pasca Sarjana Universitas Gadjah Mada Yogyakarta.

Waters, Malcolm, 1994. Modern Sociological Theory. London, Thousand Oaks, New Delhi: Sage Publications. 
